products. Some of them are manufactured in reasonably large quantities, but they are inadequate to produce the huge tonnage of rubber used in the United States. For this reason and also because of its characteristies, 'Paracon' will probably remain a speciality product. The article gives some of the properties and uses of the material.

\section{Portugaliae Physica}

A NEW Portuguese journal of physics, Portugalice Physica - the first of its kind in that country devoted entirely to physics-has been established and has published its first number. The four papers which it contains comprise a calculation of the matrix of electrostatic interaction and orbit-spin for $d^{2} p$ with an application to the spectrum of Ti II, a mathematical discussion of a group of operators with suggested application to quantum theory, and two papers on $\beta$-ray spectra with reference to internal conversion. In one of these, A. Gibert finds some evidence in support of Stahel's view that the energy quantum can be shared by more than one electron. At a time when the study of pure science has been necessarily replaced for so many by sterner pursuits, it is pleasant to realize that there are still countries where it is growing and needs new mediums for publication. Correspondence relating to the journal should be sent to Portugalice Physica, Faculdade de Ciências, R. da Escola Politécnica, Lisboa-Portugal.

\section{Libraries Board of South Australia}

THE annual report of the Libraries Board of South Australia, covering the year July 1942-June 1943, refers to the opening on July 30,1942 , of new temporary accommodation for the country lending service, with a further great increase in the number of books issued, as well as to the rapid development of the research service. The latter is now receiving inquiries from every State in Australia for its lists of scientific and technical literature. Through the Scientific Liaison Bureau it is establishing relations between bodies carrying on similar work through the Commonwealth. The Board emphasizes the urgent need for building extension to cover the expansion of the research service, etc. During the year 4,615 books were added, making a total of 197,112 and in addition to 7,500 volumes in the Symon Library and 10,757 in the country lending service. The main library catalogue now contains about 541,648 cards.

\section{Earthquakes during March 1944}

DURING this month eleven strong earthquakes were registered by the seismographs at the observatory at Toledo (Spain). The strongest to be recorded occurred on March 9, when $i P z$ registered at $22 \mathrm{~h}$. $23 \mathrm{~m}$. $24 \mathrm{~s}$. from an epicentre some $62 \cdot 5^{\circ}$ distant; the earthquake attained a maximum amplitude at Toledo of $330 \mu$ at $22 \mathrm{~h} .47 \mathrm{~m} .00 \mathrm{~s}$. The shock finished recording at $1 \mathrm{~h} .00 \mathrm{~m}$. 00s. on March 10 .

At Wellington, New Zealand, during the same month, three strong earthquakes were registered by the instruments. These occurred on March 10, 22 and 31. In addition, eleven local earthquakes were felt in New Zealand during the month. The areas where these were reported as felt were Takaka, Nelson (March 15), Taupo (three times on March 20), Puysegur Point (on March 26), and Milford Sound (on March 29).

The United States Coast and Geodetic Survey, in co-operation with Science Service and the Jesuit
Seismological Association, has determined two more provisional epicentres during the month. The earthquakes occurred on March 22 and March 31. The former was recorded at both Toledo and Wellington, and the latter at Toledo. On March 22 the earthquake happened at $0 \mathrm{~h} .43 \cdot 0 \mathrm{~m}$. G.M.T. and its epicentre, based on instrumental reports from eleven stations, was found to be at lat. $7^{\circ} \mathrm{S}$., long. $126^{\circ} \mathrm{E}$., which is in the Banda Sea. On March 31 the earthquake occurred at $20 \mathrm{~h} .34 \cdot 8 \mathrm{~m}$. G.M.T., and on instrumental reports from Fordham, Philadelphia, St. Louis and San Juan the epicentre has been calculated to have been at lat. $3^{\circ} \mathrm{S}$., long. $81^{\circ} \mathrm{W}$., which is in Ecuador.

\section{Announcements}

Prof. Peter Kapitza has been awarded the Order of Lenin on the occasion of his fiftieth birthday, in recognition of his outstanding scientific achievements in physics.

Prof. W. P. WYNne, emeritus professor of chemistry in the University of Sheffield, and a fellow of the Royal Society since 1896, has been elected a fellow of the Imperial College of Science and Technology, which he entered as a student sixty-three years ago.

The Minister of Food has appointed Mr. Angus McKenzie, teacher of bread-making at the Royal Technical College, Glasgow, as a travelling bread adviser for Scotland. Any baker wishing to avail himself of Mr. McKenzie's services should either write to the Director of Bread, Bryn Euryn, Colwyn Bay, or Mr. McKenzie at his home address, 206 Cambusnethan Street, Wishaw.

AT the annual degree congregation of the University of Birmingham, the honorary degree of D.Sc. was conferred on Ernest Ansley Watson in recognition of his distinguished contributions to electrical engineering and, in particular, of his work on magnetos and on electric lighting of mines. The honorary degree of M.D. was conferred on Dr. Harry Guy Dain, Chairman of Council of the British Medical Association. The honorary degree of Master of Surgery was conferred on William Warwick James, in recognition of his eminent work on maxillo-facial injuries.

IT has been decided to postpone the conference on "The Nutritional Role of the Micro-flora in the Alimentary Tract", which the English Group of the Nutrition Society was to have held on July 22, at the London School of Hygiene and Tropical Medicine, Keppel Street, W.C.1. An announcement concerning the revised arrangements will be made later.

THE Council of the Royal Society of Arts offers the following awards under the Thomas Gray Memorial Trust, the objects of which are "The Advancement of the Science of Navigation and the Scientific and Educational Interests of the British Mercantile Marine": a prize of $£ 50$ to any person of British or allied nationality for an invention, publication, diagram, etc., during the period January 1, 1939-December 31, 1944, which is likely to be of value in navigation; an award of $£ 50$ for a deed of professional merit by a member of the British Merchant Navy during the year ending September 30,1944 . Claims in connexion with both awards must reach the Acting Secretary, Royal Society of Arts, John Adam Street, Adelphi, London, W.C..2, before December 3], 1944. 